\section{OP0224 RESULTS OF A PHASE 2 STUDY OF RG6125, AN ANTI-CADHERIN-11 MONOCLONAL ANTIBODY, IN RHEUMATOID ARTHRITIS PATIENTS WITH AN INADEQUATE RESPONSE TO ANTI-TNFALPHA THERAPY}

Rebecca Finch ${ }^{1}$, Alexandre Sostelly ${ }^{2}$, Kim Sue-Ling ${ }^{3}$, Angela Blaeuer ${ }^{2}$, Guillemette Duchateau-Nguyen ${ }^{2}$, Lidia Ukarma ${ }^{2}$, Claire Petry², Patanjali Ravva ${ }^{2}$ Peter Villiger ${ }^{4}$, Uwe Junker ${ }^{2} .{ }^{1}$ Roche Products Ltd, Welwyn, United Kingdom; ${ }^{2}$ Roche Innovation Center Basel, Basel, Switzerland; ${ }^{3}$ Roche Innovation Center New York, New York, NY, United States of America; ${ }^{4}$ Inselspital Bern, Berne, Switzerland

Background: Cadherin-11 is expressed on fibroblasts in joints of RA patients and augments local fibroblast-mediated inflammation, pannus formation and tissue invasion (1). RG6125 is a novel humanized monoclonal antibody directed against Cadherin-11.

Objectives: To assess the safety, tolerability and efficacy of RG6125 as adjunctive treatment in patients with moderately to severely active RA and an inadequate response to anti-TNF- $\alpha$ therapy.

Methods: The Phase 2 study was conducted as a multicenter, randomized, double-blind, placebo-controlled study. Patients were randomly assigned (2:1) to receive $810 \mathrm{mg}$ of RG6125 or placebo by IV infusion. In the treatment period, patients received RG6125 or placebo IV infusions twice every two weeks and then monthly for a total of 4 dose administrations up to Week 12 . The primary efficacy endpoint was the proportion of patients with ACR50 response at Week 12. Results: Demographics: 109 patients were randomized (98 female) to either placebo $(\mathrm{N}=37)$ or $\mathrm{RG} 6125(\mathrm{~N}=72)$ and were included in the efficacy analysis population. 107 patients were included in the safety analysis population (37 placebo, 70 RG6125). The median age was 55 years $(22-78)$, and median RA disease duration was 12.4 years $(1.0-42.4)$.

Efficacy: Overall, there was little to no difference between RG6125 and placebo arms in the primary and secondary efficacy assessments (Table 1).

Safety: More frequent musculoskeletal/connective tissue (14.3\% vs. $8.1 \%)$ and gastrointestinal adverse events (12.9\% vs. $8.1 \%$ ) were noted on RG6125 compared to placebo, respectively. Two serious AEs were noted, one on RG6125 (intervertebral disc protrusion) and one on placebo (bacterial arthritis). No deaths occurred during the study.

PK/PD: Pharmacokinetics of RG6125 appears linear at the dose range tested. There was no significant relationship identified between exposure groups, defined by Cavg, and the efficacy endpoints at week 12. The kinetics of continuous endpoints was not significantly different across the exposure groups.

Table 1. Summary of Efficacy Results (Efficacy Analysis Population)

\begin{tabular}{|c|c|c|c|}
\hline & $\begin{array}{c}\text { RG6125 } 810 \mathrm{mg} \\
(\mathrm{N}=72)\end{array}$ & $\begin{array}{l}\text { Placebo } \\
(\mathrm{N}=37)\end{array}$ & $\begin{array}{c}\text { Difference - } \\
(90 \% \mathrm{Cl})\end{array}$ \\
\hline ACR50 Responders - $n(\%)$ & $8(11.1 \%)$ & $6(16.2 \%)$ & $\begin{array}{c}-5.1 \% \\
(-19.8 \%, 6.9 \%)\end{array}$ \\
\hline ACR20 Responders - n(\%) & $20(27.8 \%)$ & $16(43.2 \%)$ & $\begin{array}{c}-15.5 \% \\
(-32.4 \%, 1.6 \%)\end{array}$ \\
\hline ACR70 Responders - n(\%) & $1(1.4 \%)$ & $0(0.0 \%)$ & $\begin{array}{c}1.4 \% \\
(-7.9 \%, 7.0 \%)\end{array}$ \\
\hline $\begin{array}{l}\text { Change from Baseline in } \\
\text { DAS28 - adjusted mean* }\end{array}$ & $\begin{array}{l}-1.18 \\
(n=65)\end{array}$ & $\begin{array}{l}-1.65 \\
(n=36)\end{array}$ & $\begin{array}{c}0.48 \\
(-0.84,-0.12)\end{array}$ \\
\hline $\begin{array}{l}\text { Change from Baseline in } \\
\text { CDAI - adjusted mean }{ }^{\star}\end{array}$ & $\begin{array}{l}-14.67 \\
(n=65)\end{array}$ & $\begin{array}{l}-17.94 \\
(n=36)\end{array}$ & $\begin{array}{c}3.27 \\
(-7.47,0.94)\end{array}$ \\
\hline $\begin{array}{l}\text { Change from Baseline in } \\
\text { SDAI - mean (SD) }\end{array}$ & $\begin{array}{c}-20.69(35.29) \\
(n=63)\end{array}$ & $\begin{array}{c}-21.31(33.82) \\
(n=33)\end{array}$ & - \\
\hline $\begin{array}{l}\text { Change from Baseline in } \\
\text { HAQ-DI - mean (SD) }\end{array}$ & $\begin{array}{c}-0.24(0.51) \\
\quad(n=65)\end{array}$ & $\begin{array}{c}-0.15(0.52) \\
(\mathrm{n}=37)\end{array}$ & - \\
\hline $\begin{array}{l}\text { RAMRIS Synovitis Score - } \\
\text { median (range) }\end{array}$ & $\begin{array}{c}0.00(-6.3-4.5) \\
(n=59)\end{array}$ & $\begin{array}{c}-0.25(-4.0-2.7) \\
(n=27)\end{array}$ & - \\
\hline $\begin{array}{l}\text { RAMRIS Osteitis Score - } \\
\text { median (range) }\end{array}$ & $\begin{array}{c}0.00(-15.3-8.0) \\
(n=59)\end{array}$ & $\begin{array}{c}0.00(-13.0-1.3) \\
(n=27)\end{array}$ & - \\
\hline $\begin{array}{l}\text { RAMRIS Bone Erosion Score } \\
\text { - median (range) }\end{array}$ & $\begin{array}{c}0.00(-6.0-3.5) \\
(n=59)\end{array}$ & $\begin{array}{c}0.00(-1.0-2.5) \\
(n=27)\end{array}$ & - \\
\hline
\end{tabular}

Non-responder imputation used for missing ACR responses. LOCF used for missing SJC/TJC. For ACR missing CRP has been imputed with ESR if available. No imputation for other missing components. No imputation for missing DAS28, CDAI, SDAI, HAQ-DI or MRI RAMRIS scores.

* ANCOVA adjusted for baseline score and prior anti-TNF $\alpha$ therapy duration. MRI RAMRIS score is combination of the wrist and 1-5 MCP joints, and are exploratory endpoints.

Conclusion: RG6125 was well tolerated with only mild to moderate AEs. RG6125 did not show a discernible treatment effect in RA patients in combination with anti-TNF $\alpha$-blockers over placebo.

\section{REFERENCE:}

[1] Lee DM, et al. Science 2007;315:1006-10.

Disclosure of Interests: Rebecca Finch Shareholder of: Roche, Employee of: Roche, Alexandre Sostelly Shareholder of: Roche, Employee of: Roche, Kim Sue-Ling Shareholder of: Roche, Employee of: Roche, Angela Blaeuer Shareholder of: Roche, Employee of: Roche, Guillemette Duchateau-Nguyen Shareholder of: Roche, Employee of: Roche, Lidia Ukarma Shareholder of: Roche, Employee of: Roche, Claire Petry Shareholder of: Roche, Employee of: Roche, Patanjali Ravva Shareholder of: Roche, Employee of: Roche, Peter Villiger: None declared, Uwe Junker Shareholder of: Roche, Employee of: Roche DOI: 10.1136/annrheumdis-2019-eular.3028

\section{OP0225 SERIOUS INFECTIONS IN OFFSPRING EXPOSED IN UTERO TO NON-TNFI BIOLOGICS AND TOFACITINIB}

Evelyne Vinet ${ }^{1}$, Yvan St-Pierre ${ }^{2}$, Cristiano Moura ${ }^{2}$,Jeffrey Curtis ${ }^{3}$,

Sasha Bernatsky ${ }^{1}{ }^{1}$ McGill University, Divisions of Rheumatology and Clinical Epidemiology, Montreal, Canada; ${ }^{2}$ McGill University Health Centre Research Institute, Montreal, Canada; ${ }^{3}$ University of Alabama at Birmingham, Birmingham, United States of America

Background: During pregnancy, maternal circulating immunoglobulins G (IgG) are actively transported across the placenta through their $F c$ portion. Thus, TNFi and other biologics harbouring an Fc part have the potential to transfer across the placenta, often reaching higher fetal than maternal levels.[1] In addition, it is postulated that small-molecule drugs may cross the placenta, although this remains unconfirmed. As fetuses could be exposed to therapeutic (or potentially supra-therapeutic) levels of biologics and small molecules, there are concerns that these agents could cause immunosuppression in exposed offspring.

Objectives: We compared the risk of serious infections in children born to mothers with chronic inflammatory diseases who used non-TNFi biologics or tofacitinib during pregnancy, versus unexposed offspring and children exposed to TNFi in utero.

Methods: We identified all women with $\geq 1$ hospitalization for delivery after a diagnosis of rheumatoid arthritis (RA), ankylosing spondylitis (AS), psoriasis (PsO), psoriatic arthritis (PsA), or inflammatory bowel diseases (IBD), and a randomly selected group of unaffected mothers, matched $\geq 4: 1$ for age, year of delivery, and state of residence, using MarketScan data (2011-2016). Only women continuously enrolled within MarketScan for $\geq 12$ months prior to delivery and with available child linkage were included. We defined tofacitinib, TNFi and non-TNF biologic (i.e. abatacept, rituximab, tocilizumab, ustekinumab, vedolizumab) exposure based on $\geq 1$ filled prescription and/or infusion procedure code during pregnancy and/or the preconception period. We ascertained serious infections in the offspring based on $\geq 1$ hospitalization with infection as a primary diagnosis, within the first year of life. We also characterized all exposure groups according to maternal demographics, disease type, co-morbidities, pregnancy complications, and drug use (i.e. corticosteroids, DMARDs, biologics).

Results: We identified 16,490 offspring of mothers with RA (4,142), AS (381), $\mathrm{PsO} / \mathrm{PsA}(5,743)$, and IBD $(6,731)$, as well as 164,553 children born to unaffected matched mothers. Among offspring whose mothers had inflammatory diseases, 108 were exposed to tofacitinib or non-TNFi biologics (tofacitinib 4, abatacept 34 rituximab 6 , tocilizumab 12 , ustekinumab 42 ) and 1,611 to TNFi during pregnancy. We observed 2 cases of serious infections in children exposed to tofacitinib or non-TNFi biologics (1.9\%; $95 \% \mathrm{Cl} 0.3,7.2)$ : one case was exposed to tofacitinib, while the other was exposed to abatacept. The percent of serious infections in offspring of inflammatory disease mothers with no TNFi exposure was $2.1 \%(95 \% \mathrm{C}$ $1.9,2.3)$, while for those with TNFi in utero exposure, it was $2.3 \%(95 \% \mathrm{Cl} 1.6$, 3.0). In children born to unaffected mothers, the percent of serious infections was $1.6 \%(95 \% \mathrm{Cl} 1.6,1.7)$.

Conclusion: In the largest cohort of inflammatory disease offspring ever assembled, we detected very few serious infections in children exposed to nonTNFi biologics or tofacitinib. More studies are necessary to precisely determine the specific effects of individual non-TNFi biologic and small-molecule drugs on the risk of serious infections in exposed offspring.

\section{REFERENCE:}

[1] Vinet É, De Moura C, Pineau CA, Abrahamowicz M, Curtis JR, Bernatsky S. Serious Infections in Rheumatoid Arthritis Offspring Exposed to Tumor Necrosis Factor Inhibitors: A Cohort Study. Arthritis Rheumatol. 2018 Oct:70(10):1565-1571.

Disclosure of Interests: None declared DOI: 10.1136/annrheumdis-2019-eular.5900 